A 113

\title{
暗視野顕微鏡法による走磁性細菌の挙動可視化
}

\author{
高橋 秀治 $^{\circ}$ (東工大院), 木倉 宏成（東工大，岩佐 達郎（室蘭工大） \\ 渡辺 真悟（室蘭工大），有富 正憲（東工大）

\section{Visualization of Magnetotactic Bacteria Behavior using Dark-field Microscopy}

\author{
Hideharu TAKAHASHI, Hiroshige KIKURA, Tatsuo IWASA \\ Shingo WATANABE and Masanori ARITOMI
}

\begin{abstract}
Magnetotactic bacteria are a class of bacteria that has nano sized magnetic crystals inside their body and respond to geomagnetic field. This paper reports the experimental research on visualization of magnetotactic bacteria "Magnetospirillum Magnetotacticum" behaviors under no/DC/AC magnetic field. The motion of magnetotactic bacteria was observed using an optical dark-field microscope system. The images were taken using cameras, and measured by image processing techniques. Applying DC/AC magnetic field, it was observed that magnetotactic bacteria rotated in the direction of magnetic field.
\end{abstract}

Keywords: Magnetotactic bacteria, Màgnetosome, Ferromagnetic nano-particles, Dark-field microscopy, Magnetic field

\section{1.はじめに}

ナノテクノロジーの発展に伴い, Micro Total Analysis System ( $\mu$-TAS) や Micro Electro-Mechanical System (MEMES) などのマイクロ・ナノデバイスに関する研究 開発が盛んに行われている。このようなデバイス中にお いてマイクロスケールでの流動制御を目的とし，近年， 外部磁場による非接触制御が可能な磁気機能性流体ある いは強磁性微粒子をこれらデバイス中で応用する研究が なされている。また，この磁気に忘答する機能性を持つ 材料をドラッグデリバリー，バイオスクリーニング, MRI 用造影剤, ハイパーサミア等の医療分野へ応用する という研究もまた期待され活発に行われている 1).

かかる状況下, 著者らはマイクロデバイス中での流れ 場制御を外部磁場により効率良く行えるマイクロ流動制 御技術を開発することを目的に，磁気機能性流体として 水べ一ス磁性流体に着目し，特に，静磁場作用下におけ る, 強磁性ナノ微粒子の振る舞いに関して研究を行って きた。

一方，人工的に作製される磁性流体中の強磁性ナノ微 粒子とは異なり，粒子径 50〜 150nm ほどの強磁性ナノ 微粒子を体内で生成する走磁性細菌が発見され2), その 強磁性ナノ微粒子の生成過程に関する研究や，その細菌
自身の行動特性・材料特性に関する研究が活発に行われ ている ${ }^{3) 4)}$. 走磁性細菌はマグネトソーム(Magnetosome) と呼ばれるマグネタイト $\left(\mathrm{Fe}_{3} \mathrm{O}_{4}\right)$ 微粒子の連なりを体内 に生成し，このマグネトソームを磁気センサーとして地 磁気の方向を認識することで自身の成長に理想的な環境 である微好気条件下を目指し移動することができる.

著者らは, 走磁性細菌の中でも, 特に螺旋形状の走磁 性細菌 Magnetospirillum magnetotacticumに着目した。 本報告においては，無磁場下・磁場作用下におけるこの 細菌の挙動を解明することを目的とし, 暗視野顕微鏡法 を用い挙動可視化・観察を行った結果について述べる。

\section{2. 実験装置及び方法}

Fig. 1 に実験装置の概略図を示す. 本実験においては, 走磁性細菌 Magnetospirillum magnetotacticum を フのビタミン溶液及びミネラル溶液を含む培養液中に分 散させ, その溶液を $76 \times 26 \times 1 \mathrm{~mm}$ のスライドグラス上に マイクロピペットで $5 \mu \mathrm{l}$ 添加し, $22 \times 22 \times 0.17 \mathrm{~mm}$ のカバ 一グラスで挟み込み薄膜状にした。これを試料とし光学 顕微鏡(Olympus BX50)を用いて可視化，観察を試みた. 細菌を精細かつ高コントラストに可視化するため, 光学 顕微鏡に油浸式暗視野コンデンサレンズ(OLYMPUS $\mathrm{U}-\mathrm{DCW})$ 取り付け，サンプルからの散乱光のみを対物 


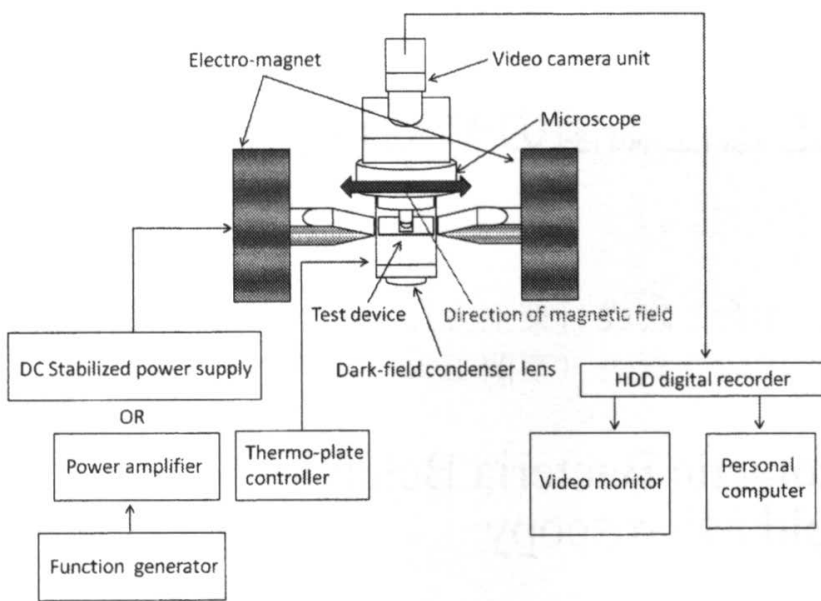

Fig. 1 Schematic diagram of experimental apparatus

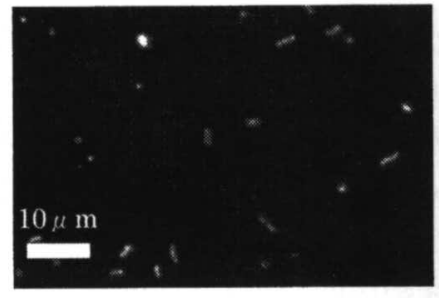

(i ) Under no magnetic field

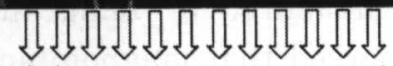

(ii) Under DC magnetic field

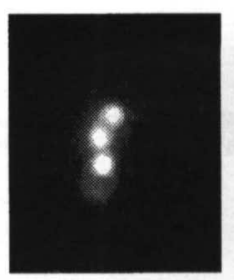

$\mathrm{t}=0[\mathrm{sec}]$

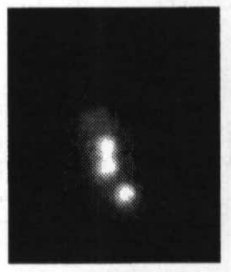

$\mathrm{t}=0.3 \mathrm{~T}[\mathrm{sec}]$

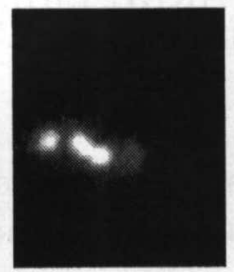

$\mathrm{t}=0.6 \mathrm{~T}[\mathrm{sec}]$

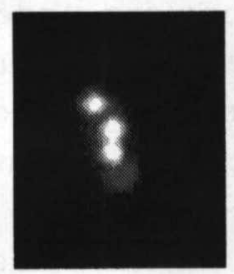

$\mathrm{t}=0.9 \mathrm{~T}[\mathrm{sec}]$

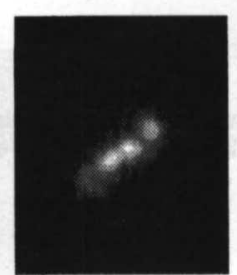

$\mathrm{t}=0.1 \mathrm{~T}[\mathrm{sec}]$

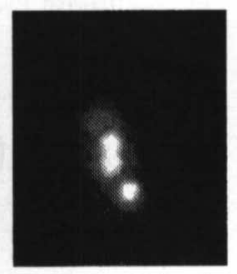

$\mathrm{t}=0.4 \mathrm{~T}[\mathrm{sec}]$

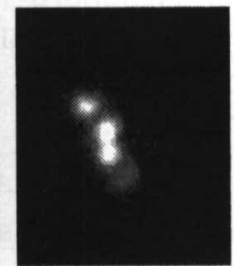

$\mathrm{t}=0.7 \mathrm{~T}[\mathrm{sec}]$

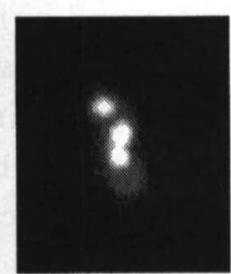

$\mathrm{t}=1.0 \mathrm{~T}[\mathrm{sec}]$

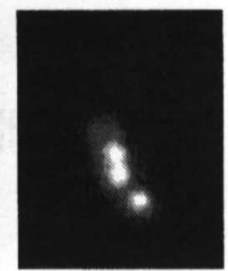

$\mathrm{t}=0.2 \mathrm{~T}[\mathrm{sec}]$

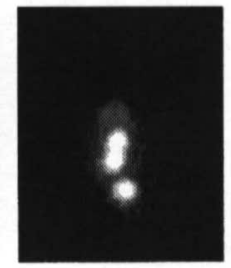

$\mathrm{t}=0.5 \mathrm{~T}[\mathrm{sec}]$

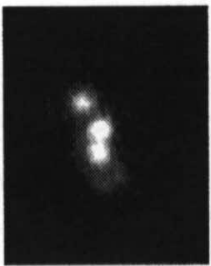

$\mathrm{t}=0.8 \mathrm{~T}[\mathrm{sec}]$

$5 \mu \mathrm{m}$

Fig. 2 Visualized images of magnetotactic bacteria under DC magnetic field (permanent magnet)

レンズを通して結像させる暗視野法により可視化を行っ た。円筒型誘導電磁石を試験領域両サイドに設置し, 無 磁場下（本実験条件においては, 微小な地磁気の影響は 除外して考えている。) だけでなく, DC 磁場， AC (Sin 波形）磁場作用下における細菌の挙動も観察した。可視 化画像は, 鏡塔に設置したカメラ (NIKON D-50) 及び, ビデオカメラ (OLYMPUS CSS-330, WATEC NEPTUNE-100)を用いて撮像され，その後パーソナル コンピュータに取り込まれ画像処理計測された.

\section{3. 実験結果及び考察}

暗視野法により, 螺旋形状の走磁性細菌がコントラス トよく可視化できた，無磁場下では，走磁性細菌はブラ ウン運動をしながら, ある場所に定位するか, 鞭毛運動 をしている様子が観察された。 DC 磁場 (永久磁石) 作用 下では，多くの走磁性細菌が磁力線方向に配向する様子 が観察された(Fig. 2). AC 磁場作用下では, 走磁性細菌 が周波数に依存し, 時計回りあるいは反時計回りに回転 する様子が観察された(Fig. 3)。図中 T は周期 (=1/周波 数)である. 磁場周波数が増加するに伴い, その回転の応 答性は悪くなった。この現象は細菌体内のマグネトソー ムの外部磁場に対する磁化の緩和時間が関係していると 考えられ，外部磁場作用下におけるこの回転応答とマグ ネトソーム量の関係について,今後, 調べる必要がある.

Fig. 3 Visualized images of magnetotactic bacterium rotation under $\mathrm{AC}$ magnetic field $(1 \mathrm{~Hz})$

\section{4. おわりに}

走磁性細菌の挙動可視化に関して, 暗視野顕微鏡可視 化システムの適用性が示された．また，可視化観察によ り，走磁性細菌の挙動が外部磁場により影響されること や, 細菌の回転挙動が外部印加 $\mathrm{AC}$ 磁場周波数に依存す ることが判った. 今後, 定量的評価を導き出すために, 細菌の寿命や培養方法による影響等も踏まえた挙動観察 を行う予定である。

\section{参考文献}

1) Ito A. et al: Medical Application of Functionalized Magnetic Nanoparticles, J. Biosci. Bioeng., Vol. 100, No. 1 (2005) pp. 1-11.

2) Blakemore R. : Magnetotactic Bacteria, Science, Vol. 190, No. 4212 (1975) pp. 377-379.

3) Schuler D., Frankel R. B.: Bacterial magnetosomes: microbiology, biomineralization and biotechnological applications, Appl. Microbiol. Biotechnol., Vol.52, No. 4 (1999) pp. 464-473.

4) Matsunaga T. et al: Drug delivery by magnetoliposomes containing bacterial magnetic particles, Cell. Eng., Vol. 2, (1997) pp. 7-11. 